\title{
ANALYSIS OF PROJECT DELAY RISK FACTORS OF BUILDING DEVELOPMENT IN HUMAN SETTLEMENTS DIVISION OF EAST KUTAI REGENCY'S PUBLIC WORKS SERVICE OFFICE
}

\author{
Adelina Nenny*, Researcher \\ Kustamar, Lecturer \\ National Institute of Technology, Malang, East Java, Indonesia \\ *E-mail: enkapi2704@gmail.com \\ ORCID: 0000-0001-8660-1541
}

\begin{abstract}
The objectives of this research are 1) analyze the factors affecting project delay in building development project, 2) analyze the most dominant factor affecting project implementation delay in the building development project, 3) determine the actions that should be done on the dominant risks in affecting project implementation delay. The studied project is Building Development Project of Human Settlements Division of East Kutai Regency's Public Works Service Office. From the hypothesis testing results of simultaneous regression model using $F$ test; it is found that $F_{\text {count }}$ result is smaller than $F_{\text {table }}(1,079<2,270)$. Besides, $p$-value is found of 0.396 . If $p$-value compared to $\alpha=0.05$, then $p$-value is bigger than $\alpha=0.05$. From both comparisons, it can be concluded that $\mathrm{H}_{0}$ is accepted in the standard of $\alpha=0.05$. Therefore, it is concluded that there is no simultaneous significant effect among factors of $\mathrm{X} 1, \mathrm{X} 2, \mathrm{X} 3, \mathrm{X} 4, \mathrm{X} 5, \mathrm{X} 6$ and $\mathrm{X} 7$ on project implementation delay. The most dominant factor affecting building development project implementation delay is Implementation Method Factor (X5) which has regression coefficient of $-0,086$. By using the help of SPSS software, it is found that $\beta$ coefficient is of $-0,086$ and also $p$-value is smaller than $\alpha=0.05$.
\end{abstract}

\section{KEY WORDS}

Project, development, building, public service.

In the building construction project implementation of Sangatta City, East Kutai Regency, it is frequently found and heard that the project has problems causing to effects on the construction implementation. Based on data obtained from Public Works Service Office on Human Settlements Division of East Kutai Regency, the building project implementation in budget year of 2016, there are 8 work packages that have implementation delay ranging \pm $15-18 \%$ (data source, 2016) from the determined time, which causes effect on contract changes/extra time addendum. It is assumed that it happens because of factors such as human resources (workers), implementation method, planning, material, equipment, and supervision; however, up to now, there is no research investigating about this.

In the punctual consruction project implementation, it can be stated that it is profitable for both parties; thus, a good company will always attempt to implement it based on the determined time or attempt to minimize the delay by choosing corrective action that needs to be done and make a decision based on analysis from some delay factors. Therefore, a review is needed to identify and analyze the factor that affects the project delay.

The questions in this research that can be formulated from the previous explanation are as follows:

- What factors that affect the delay of building development Project in Human Settlement Division in Public Works Service Office in East Kutai Regency?

- What is the most dominant factor which affects the delay of building development Project in Human Settlement Division in Public Works Service Office in East Kutai Regency?

- What action should be taken to minimize the delay of building development Project in Human Settlement Division in Public Works Service Office in East Kutai Regency? 
Based on the research questions aforementioned, the objectives of this research are:

- To analyze the factors which affect the delay of building development Project in Human Settlement Division in Public Works Service Office in East Kutai Regency;

- To analyze the most dominant factor affecting the delay of building development Project in Human Settlement Division in Public Works Service Office in East Kutai Regency;

- To determine the action that should be counted for the dominant risks in affecting the project implementation delay.

\section{LITERATURE REVIEW}

The characteristic of construction project can be seen in three dimensions, namely unique, involving resources, and needing organization (Gould \& Joyce, 2003). The goal achievement is not done through repeated or routine activities as in the organization generally. Project, according to Ervianto (2003), is a set of activities that can be planned in it by using finance sources, workers, and others to obtain benefits or results in the near future. This project activity is in the beginning and in the end.

In achieving the goal, project activity has triple constraints meaning a significant parameter to measure the success of a project implementation. These three things are Sturzenegger et al., (2016): 1. Right Budget Calculation (Cost); 2. Punctual, and 3. Performance (Scope \& Quality).

Management of Construction Project. Project management is an attempt or an activity of planning, organizing, actuating, and controlling company's resources to achieve short-term targets which have been determined previously efficiently and effectively (Olander, 2007). The activity flow in the project management vertically and horizontally is done by using system approach. Thus, management is a process consisting of actions of planning, organizing, actuating, and controlling in which in its field, it uses both knowledge andd skill and is followed systematically in order to achieve the targets which have been determined (Chan et al., 2004).

The Delay of Project Implementation. According to Ervianto (2004), delay is the implementation time which is not used as the activity plan so that it makes one or other following activities become delayed or not implemented as the determined schedule.

In this part, it will be discussed some expert opinions regarding to the causes of delay. The delay of the construction project will be grouped into 2 (two) categories (Ervianto, 2004), namely:

- Excusable Delay is the failure of construction management party in fulfillinf the accomplishment time as in the agreed contract. The causes of the delay in the project are design problem, workers change by project owner, weather influence/not in a normal condition, workers conflict, and natural disasters;

- Nonexcusable Delay is a condition in project delay caused by contstruction management party. The causes of failure in this category are bad implementation planning done by the contractor, the unskilled human resources owned by the contractor, and the failure of sub-contractor.

Nonexusable delay can lead to termination of contract. Generally, nonexcusable delay will never get extra time but the contractor will mark up in the schedule by accelerating the project.

According to Istimawan Dipohusodo (1996), during construction process, periodic dearth indication always appears on the used materials, in form of basic goods or finished goods both local and imported goods. The ways to control the delay are:

- Adding resources;

- Releasing obstacles or other attempts to guarantee that the project is increasing and bringing it back to the plan line;

- If it is impossible to be on the initial plan line, schedule revision is probably needed which is then to be used as the base of the next project progress assessment. 
Identification of Risks. "Identification of risks is a process of identifying the risks from uncertainty which is done systematically and gradually". (Smith et. al., 2009) By referring to the above definition, the causing factors that affect project delay in the group are as follows:

- Finance;

- Human Resources;

- Material;

- Equipment;

- Project Implementation Method;

- Design Change;

- Work Environment.

Definition of Questionnaire. Questionnaire is a number of written questions used to obtain information from respondent in form of the report of personality or something that he/she knows (Arikunto, 2006). Questionnaire is used to mention method or instrument. Therefore, in using questionnaire method, the used instrument is questionnaire.

Population and Sample. What is meant by population is a set of individuals with certain qualities; the quality or the characteristic is what is called variable. A population with a number of certain individuals is called finite population. Besides, what is meant as sample is a group of sampling unit taken and is the sub of population. Population is determined based on experience in the field from people who are considered experienced and knowing about development process. Moreover, those people are in their own institution or company. While, sample is taken from population which considered representative of all institution or company (Sugiyono, 2006).

Statistics is a science and an art of development and the most effective implementation method in avoiding wrong consideration in a conclusion and estimation which can be predicted based on mathematical probabiity (Supranto, 2001). In accomplishing analysis and statistics, there are some problem-solving steps namely: identifying problems or opportunities, collecting available facts correctly, collecting original data through interview, questionnaire spreading, and so on.

Validity is a measurement showing the levels of validity of an instrument. An instrument is considered valid if it can reveal data from the studied variable correctly. The high and low validity of an instrument show how far the collected data is not out of the overview of the validity (Riduwan, 2005).

Reliability refers to a definition that an instrument is reliable enough to be used as a data collector tool because the instrument is good enough. Reliability test is done by testing the instrument (once use), then the obtained data is analyzed with certain technique. To test reliability, Alpha Cronbach method is used (Sugiyono, 2006). Alpha Cronbach method is used to look for the instrument reliability in which its score is nether neither 1 nor 0 (yes and no).

Statistics in a wide definition called inferential or inductive statistics or probability statistics, Statistika dalam arti luas biasa disebut dengan inferensial atau statika induktif atau statistika probabilitas, is a tool of collecting data, making a conclusion, making an action based on the collected data analysis or statistics used to analyze sample data and the results are used (generalized) for population (Riduwan, 2005).

Factor analysis is an analysis which is commonly provided for classes in multivariate statistics method in which its main purpose is to minimize data and summarize it. Thus, factor analysis aims to find a way of summarizing the existing information in the original variable (initial) to be a set of new dimension or variate (factor). It is done by determining the structure through summarization data or through reduction data. Factor analysis identifies structure between variables or respondents by considering correlation between variables or correlations among respondents.

Multiple linear regression analysis is an analysis used to know the form of relation or influence between some independent variables on dependent variables. In this research, the researcher limits this research objective only for two multiple linear regression objectives which are to know the form of relation/influence between independent variables and 
dependent variables. Besides, the researcher is also willing to know independent variable which is the most affecting on dependent variables. To know the most affecting factor on a variable, regression analysis technique is used by seeing the number of the biggest regression coefficient, $F$ test (ANOVA) towards regression model simultaneously, Value of $\mathrm{R}^{2}$ (determination coefficient). Internal factor is independent variable which affects dependent variable.

\section{METHODS OF RESEARCH}

The studied Projects are the Building Development Projects of Human Settlements Division of Public Works Office in East Kutai Regency which are in the category of Project implementation delay which are as follows:

- Development Project of Regional Employment Agency Building of East Kutai Regency located in Sangatta City;

- Development Project of Forestry Office Buiding of East Kutai Regency located in Sangatta City;

- Development Project of Teluk Pandan District Office located in Teluk Pandan.

The method of data collection used takes material from some supporting sources in the development related to the studying object, the data are obtained by: providing direct data (primary data) and providing indirect data (secondary data).

Data collection is obtained through interview and spreading questionnaire sheets to the respondents. Questionnaire is in the form of questions arranged based on literatura from field observation, in which every questions are related to the factors which cause building Project development delay in Human Settlements Division of Public Works Office in East Kutai Regency in which the respondents can select one of the answer choices.

In this research, secondary data is data or information obtained from literature study which is data which have been processed including: Data used as a theory basis of the research, obtained from books, journals, articles, previous related researches, and data from project. The data are Tender Documents, Contract Documents, Project Figures, Time Schedule containing project implementation delay data.

Popuation of the present research is the people who know the condition and get involved directly in the project of Regional Employment Agency Office Building Development of East Kutai Regency, Forestry Office Buiding Development of East Kutai Regency, and Teluk Pandan District Office Development in budget year 2016 in which the population total is of 50 people.

In this research, sample is taken randomly by using disproportionate stratified random sampling (Sugiono, 2006) with the formula according to Slovin in Husein Umar 2007 which is as follows:

$$
\mathrm{n}=\frac{\mathrm{N}}{1+\mathrm{N}^{2}}
$$

Where: $\mathrm{n}$ - Sample Size; N - Population Size = 50; E: Looseness Percentage = 0,05.

Factor Analysis. The factor analysis used in the present research is to confirm the indicator of each factors which have been determined whether it is indeed the indicators that are in line with the factors or not, and analyze the factors which are taken as the overview of the project implementation delay causes. In this analysis, it obtains information about data structure as the effect of the project implementation delay. The result of factor analysis towards 2 variables assumed as the effect of the project implementation delay will test its variables properness to know the relation of its variables or indicators.

Multiple Linear Regression Analysis. In order to test the questions regarding to what factors affecting the project implementation delay in the Development Project of Regional Employment Agency Building of East Kutai Regency, Development Project of Forestry Office Buiding of East Kutai Regency, and Development Project of Teluk Pandan District Office, and what is the most dominant factor; the analysis technique used is multiple linear 
regression test. This test is used to investigate or analyze the effect or the relation between independent variables with one or more variables. In analysis technique, Annova test or $f$ test, $t$ test are used and in order to find the number of determination coefficient or $R^{2}$ adjusted, this test will employ SPSS program as in the multiple linear equation.

\section{Table 1 - Definition of Research Variable}

\begin{tabular}{|c|c|}
\hline Variables & Definitions \\
\hline Finance & $\begin{array}{l}\text { Finance is the fund provided by the contractor to produce a product that is expected starting from } \\
\text { material procurement, wages payment, operational equipment, and other until the product can function } \\
\text { well as in line with the goal from the project. According to Soeharto, 1999, finance/capital is the part of } \\
\text { project resources used to develop installation or to product the expected project product, starting from } \\
\text { the expense of properness study, engineering design, procurement, pabrication, construction untul } \\
\text { installation or the product can completely function. }\end{array}$ \\
\hline Material & $\begin{array}{l}\text { Material is the available goods with certain specifications and is used to accomplish development } \\
\text { project, both seen from the number, form, and the size. Its indicator category is the increase of } \\
\text { material price, the delay of material delivery, bad quality of material, inadequate number of material, } \\
\text { improper volume and material type, and waste material. }\end{array}$ \\
\hline Human Resources & $\begin{array}{l}\text { Workers are people who get involved directly in the development implementation with the ability to } \\
\text { perform duties as in their fields and responsibilities given to them. Its indicator category is the lack of } \\
\text { workers availability, the less skilled workers, the lack of skilled workers used when project } \\
\text { implementation, the lack of project manager experience. }\end{array}$ \\
\hline Equipment & $\begin{array}{l}\text { The equipment delay is mostly caused by the damaged equipment condition and the lack of heavy } \\
\text { equipment operator, so that it leads to the delay possibility towards the works which affect time of the } \\
\text { project implementation. Its indicators are the condition of the used equipment, Efficiency of working } \\
\text { equipment, equipment operator (expert in their fields), and the number of equipment used (the delat of } \\
\text { working equipment repair) }\end{array}$ \\
\hline $\begin{array}{l}\text { Implementation } \\
\text { Method }\end{array}$ & $\begin{array}{l}\text { In work, we should determine the working method so that the works can be in line with what has been } \\
\text { planned and on time as what is planned. If the method is not right, then the work will have a delay. } \\
\text { Furthermore, its indicators are application of work implementation and the change of the method. }\end{array}$ \\
\hline Design Change & $\begin{array}{l}\text { Design Change is the shifting/changing/reviewing activity of the existing design in the project } \\
\text { implementation, the work which is not in line with the initial plan (in terms of unachieved construction } \\
\text { dimension) which makes the work should be fixed and the mistakes in the initial design which has } \\
\text { been made that leads to design review. }\end{array}$ \\
\hline Work Environment & $\begin{array}{l}\text { Work Environment is the situation of the existing site and the condition of social culture involving in a } \\
\text { project. A good work environment will motivate individuals to work happily and increase responsibility } \\
\text { to obtain better work results. }\end{array}$ \\
\hline
\end{tabular}

Table 2 - Research Variables and Indicators (X Variable)

\begin{tabular}{|c|c|}
\hline Variables & Research Variables Indicators \\
\hline \multirow{4}{*}{ Finance $(\mathrm{X} 1)$} & Payment delay done by the contractor to the workers (X1.1) \\
\hline & Payment delay done by the contractor to the supplier (X1.2) \\
\hline & Payment delay done by the owner to the contractor (X1.3) \\
\hline & The contractor's finance capacity (X1.4) \\
\hline \multirow{6}{*}{ Material (X2) } & The increase of material price $(\mathrm{X} 2.1)$ \\
\hline & The delay of material delivery (X2.2) \\
\hline & Bad material quality (X2.3) \\
\hline & Inadequate material numbers available (X2.4) \\
\hline & Improper material type (X2.5) \\
\hline & Waste material (X2.6) \\
\hline \multirow{4}{*}{ Human Resources (X3) } & Dearth of workers availability (X3.1) \\
\hline & Unskilled workers (X3.2) \\
\hline & The limited unskilled workers in the project implementation (X3.3) \\
\hline & The lack of the project manager's experience (X3.4) \\
\hline \multirow{4}{*}{ Equipment (X4) } & The condition of equipment used (X4.1) \\
\hline & The efficiency and the specialization of working tools (X4.2) \\
\hline & The equipment operator (expert in their fields) (X4.3) \\
\hline & The number of equipment used (the delay of working tools repair) (X4.4) \\
\hline \multirow{4}{*}{$\begin{array}{l}\text { Implementation Method } \\
\text { (X5) }\end{array}$} & The appropriateness of the project implementation method with the planning (X5.1) \\
\hline & The lack of ability in using the right method (X5.2) \\
\hline & The project implementation is not in line with the specification (X5.3) \\
\hline & The use of equipment, material, and workers which are not in line (X5.4) \\
\hline \multirow{3}{*}{ Design Change (X6) } & The design change done by owner (X6.1) \\
\hline & The delay of change process from planning (X6.2) \\
\hline & The initial planning is not fulfilled (X6.3) \\
\hline \multirow{3}{*}{ Work Environment (X7) } & The frequent rain $(\mathrm{X} 7.1)$ \\
\hline & The condition of working site (X7.2) \\
\hline & The condition of the topography (X7.3) \\
\hline Project Delay (Y) & $\begin{array}{l}\text { The project implementation of Human Settlements Division Building Development in East Kutai } \\
\text { Regency Public Works Service Office has delay on it. (Y) }\end{array}$ \\
\hline
\end{tabular}




\section{RESULTS OF STUDY}

The total of population and sample can be seen in table 3 as follows:

Table 3 - The Total of Population and Sample

\begin{tabular}{|l|c|c|c|c|c|}
\hline \multicolumn{1}{|c|}{ Elements } & $\begin{array}{c}\text { Regional } \\
\text { Employment } \\
\text { Agency (BKD) }\end{array}$ & $\begin{array}{c}\text { Forestry } \\
\text { Office }\end{array}$ & $\begin{array}{c}\text { District } \\
\text { Office }\end{array}$ & $\begin{array}{c}\text { Total } \\
\text { of Population }\end{array}$ & $\begin{array}{c}\text { Total } \\
\text { of Sample }\end{array}$ \\
\hline Owner: & 1 & 1 & 1 & 3 & 1 \\
- Budget User/Budget Authority (PA/KPA) & 1 & 1 & 1 & 3 & 2 \\
- Commitment Making Official (PPK) & 2 & 1 & 1 & 4 & 4 \\
- Supervisor & 1 & 1 & 1 & 3 & 2 \\
\hline Contractor: & 1 & 1 & 1 & 3 & 3 \\
- Director & 1 & 1 & 1 & 3 & 3 \\
-Project Manager & 1 & 1 & 1 & 3 & 3 \\
-Site Manager & 1 & 1 & 1 & 3 & 3 \\
- Supervisor & 1 & 1 & 1 & 3 & 3 \\
- Logistic & 1 & 1 & 1 & 3 & 3 \\
- Drafter & 4 & 3 & 3 & 10 & 9 \\
- Foreman & 1 & 1 & 1 & 3 & 3 \\
- Personality & 1 & 1 & 1 & 3 & 3 \\
\hline Consultant: & 1 & 1 & 1 & 3 & 3 \\
-Site Engineer & 18 & 16 & 16 & 50 & 45 \\
-Quality Engineer & & & & \\
-Chief Inspector & & & & 3 \\
\hline Total & & & & 3 \\
\hline
\end{tabular}

Validity test of each variable item of Finance, Equipment, Workers, Material, Implementation Method, Design Change, and Work Environment in this present research is done with the help of SPSS 20 for Windows, as seen in table 4 below:

Table 4 - Validity Test Result

\begin{tabular}{|c|c|c|c|c|c|}
\hline Factors & Indicators & Correlation Coefficients & Value of $r_{\text {table }}$ & $P$-Value & Result \\
\hline \multirow{4}{*}{ Finance (X1) } & $\mathrm{X} 1.1$ & 0,900 & 0,301 & 0,000 & Valid \\
\hline & $\mathrm{X} 1.2$ & 0,766 & 0,301 & 0,000 & Valid \\
\hline & $\mathrm{X} 1.3$ & 0,540 & 0,301 & 0,000 & Valid \\
\hline & $\mathrm{X} 1.4$ & 0,881 & 0,301 & 0,000 & Valid \\
\hline \multirow{6}{*}{ Material (X2) } & $\mathrm{X} 2.1$ & 0,554 & 0,301 & 0,000 & Valid \\
\hline & $\mathrm{X} 2.2$ & 0,766 & 0,301 & 0,000 & Valid \\
\hline & $\mathrm{X} 2.3$ & 0,497 & 0,301 & 0,001 & Valid \\
\hline & $\mathrm{X} 2.4$ & 0,576 & 0,301 & 0,000 & Valid \\
\hline & $\mathrm{X} 2.5$ & 0,513 & 0,301 & 0,000 & Valid \\
\hline & $\mathrm{X} 2.6$ & 0,604 & 0,301 & 0,000 & Valid \\
\hline \multirow{4}{*}{ Human Resources (X3) } & X3.1 & 0,865 & 0,301 & 0,000 & Valid \\
\hline & X3.2 & 0,820 & 0,301 & 0,000 & Valid \\
\hline & X3.3 & 0,446 & 0,301 & 0,002 & Valid \\
\hline & $\mathrm{X} 3.4$ & 0,666 & 0,301 & 0,000 & Valid \\
\hline \multirow{4}{*}{ Equipment (X4) } & $\mathrm{X} 4.1$ & 0,585 & 0,301 & 0,000 & Valid \\
\hline & $\mathrm{X} 4.2$ & 0,596 & 0,301 & 0,000 & Valid \\
\hline & $\mathrm{X} 4.3$ & 0,793 & 0,301 & 0,000 & Valid \\
\hline & $\bar{X} 4.4$ & 0,759 & 0,301 & 0,000 & Valid \\
\hline \multirow{4}{*}{ Implementation Method (X5) } & $\mathrm{X} 5.1$ & 0,824 & 0,301 & 0,000 & Valid \\
\hline & $\mathrm{X} 5.2$ & 0,783 & 0,301 & 0,000 & Valid \\
\hline & $\times 5.3$ & 0,553 & 0,301 & 0,000 & Valid \\
\hline & $\mathrm{X} 5.4$ & 0,621 & 0,301 & 0,000 & Valid \\
\hline \multirow{3}{*}{ Design Change (X6) } & $\mathrm{X} 6.1$ & 0,786 & 0,301 & 0,000 & Valid \\
\hline & $\mathrm{X} 6.2$ & 0,797 & 0,301 & 0,000 & Valid \\
\hline & $\mathrm{X} 6.3$ & 0,751 & 0,301 & 0,000 & Valid \\
\hline \multirow{3}{*}{ Work Environment (X7) } & $\mathrm{X} 7.1$ & 0,864 & 0,301 & 0,000 & Valid \\
\hline & $\mathrm{X} 7.2$ & 0,649 & 0,301 & 0,000 & Valid \\
\hline & $\mathrm{X} 7.3$ & 0,732 & 0,301 & 0,000 & Valid \\
\hline
\end{tabular}

Reliability test uses the help of SPSS 20 softward in which it obtains reliability test result using coefficient of Cronbach'sAlpha for variables: Finance (X1), Material (X2), Human 
Resources (X3), Equipment (X4), Implementation Method (X5), Design Change (X6), Work Environment (X7) as seen in Table 4.3 as follows:

Table 5 - Reliability Test Result

\begin{tabular}{|c|c|c|}
\hline Variables & Cronbach's Alpha & Result \\
\hline Finance (X1) & 0,787 & Reliable \\
\hline Material(X2) & 0,624 & Reliable \\
\hline Human Resources (X3) & 0,673 & Reliable \\
\hline Equipment (X4) & 0,614 & Reliable \\
\hline Implementation Method (X5) & 0,659 & Reliable \\
\hline Design Change (X6) & 0,668 & Reliable \\
\hline Work Environment (X7) & 0,611 & Reliable \\
\hline
\end{tabular}

From Table 5, coefficient of Cronbach's Alpha is obtained for variables of Finance (X1), Material (X2), Human Resources (X3), Equipment (X4), Implementation Method (X5), Design Change (X6), Work Environment (X7) which are bigger than 0,600 . Therefore, it can be concluded that the indicator used to measure the variables are reliable.

\section{DISCUSSION OF RESULTS}

Data analysis test related to the factors affecting the project implementation delay in Building Development Projects of Human Settlements Division of Public Works Office in East Kutai Regency is done descriptively with frequency distribution, which is calculating the percentage of average value of each question item to picture the achievement level of criteria if compared to the determined criteria. Descriptive Analysis can be explained that the respondents agree that the factors affecting the Project implementation delay are Human Resources of $44 \%$ and Design Change of $71,1 \%$.

From factor extraction result continued with inpreting loading factor of each item, it is shown that Laten Variables of Finance (XI), Equipment (X2), Workers (X3), Material (X4), Implementation Method (X5), Design Change (X6) and Work Environment (X7) can be formed by grouping manifest variables, which are summarized as follows:

- Finance Variable (XI), is formed with manifest variable indicator consisting of: payment delay by contractor to the workers (X1.1), Payment delay by contractor to the supplier (X1.2), Payment delay by owner to the contractor (X1.3), and the Contractor's Finance Capacity X1.4);

- Equipment Variable (X2), is formed with manifest variable indicator comprising of: the Increase of Material Price (X2.1), the Delay of Equipment Delivery (X2.2), Bad material quality (X2.3) and Waste material (X2.6);

- Human Resources Variable (X3), is formed with manifest variable indicator comprising of: The Lack of Workers available (X3.1), Unskilled Workers (X3.2), the skilled workers are limited when implementing the project (X3.3) and the Lack of Project Manager's Experience (X3.4);

- Equipment Variable (X4), is formed with manifest variable indicator comprising of: The Condition of Equipment Used (X4.1), The Efficiency and the Specialization of the Working Tools (X4.2), The Equipment Operator (expert in the field) (X4.3) and the Number of Equipment Used (the delay of working tool repair)(X4.4);

- Implementation Method Variable (X5), is formed with manifest variable indicator comprising of: The appropriateness of the project implementation method with the planning (X5.1), The lack of ability in using the right method (X5.2), The project implementation is not in line with the specification (X5.3), and The use of equipment, material, and workers which are not in line (X5.4);

- Design Change Variable (X6), is formed with manifest variable indicator comprising of: The design change done by owner (X6.1), The delay of change process from planning (X6.2), and The initial planning is not fulfilled (X6.3); 
- Work Environment Variable (X7), is formed with manifest variable indicator comprising of: The frequent rain (X7.1), The condition of working site (X7.2), and The condition of the topography (X7.3).

Regression Analysis is used to obtain factors affecting Time Delay and the most dominant factors affecting Time Delay in the data processing by using multiple linear regression analysis which employs some steps to find the relation between independent and dependent variables. Based on data processing result using SPSS.20 software, the summary is obtained shown in Table 6 as follows:

Table 6 - Summary of Regression Analysis Result

\begin{tabular}{|c|c|c|c|c|}
\hline Variables & Coefficient $ß$ & $t_{\text {count }}$ & $P$-value & Detail \\
\hline Constants & 6,625 & 5,035 & 0,000 & Significant \\
\hline Finance Factor $(\mathrm{XI})$ & 0,019 & 0,450 & 0,655 & Not significant \\
\hline Equipment Factor (X2) & 0,013 & 0,334 & 0,740 & Not significant \\
\hline Human Resources Factor (X3) & $-0,065$ & $-1,405$ & 0,168 & Not significant \\
\hline Material Factor (X4) & $-0,065$ & $-1,637$ & 0,110 & Not significant \\
\hline Implementation Method Factor (X5) & $-0,086$ & $-1,998$ & 0,050 & Not significant \\
\hline Design Change Factor (X6) & $-0,053$ & $-1,105$ & 0,276 & Not significant \\
\hline Work Environment Factor (X7) & 0,008 & 0,162 & 0,872 & Not significant \\
\hline $\begin{array}{l}\alpha=0,05 \\
\mathrm{R}^{2}=0,169 \\
\mathrm{R}=0,412 \\
\mathrm{~F} \text {-count }=1,079 \\
\mathrm{~F} \text {-table }(0.05,7,37)=2,270 \\
p \text {-value }=0.396 \\
\text { t-table }(0.05,37)=1,687\end{array}$ & & & & \\
\hline
\end{tabular}

Based on table 7 , it is seen that not all independent variables have significant value. Independent variable which has significant value (affecting significantly towards Project Implementation Delay) is Implementation Method Factor. While, the variables which do not have significant value (affecting but not significantly towards Project Implementation Delay) are Finance, Material, Human Resources, Equipment, Design Change, and Work Environment.

Strategy Analysis to Prevent Project Implementation Delay. Based on the analysis results of some analysis tools used, it is obtained that in Descriptive Analysis, it can be explained that the respondents agree that the factors affecting project implementation delay are Human Resources and Design Change factors. Regression analysis reveals that Implementation Method factor is the factor affecting significantly. Thus, it can be concluded the factors affecting insignificantly are Materialm Equipment, Design Change, and Work Environment factors. Afterwards, the factors affecting significantly the project implementation delay consist of Implementation Method factor which is the reduction result of manifest variables comprising of The appropriateness of the project implementation method with the planning (X5.1), The lack of ability in using the right method (X5.2), The project implementation is not in line with the specification (X5.3), and The use of equipment, material, and workers which are not in line (X5.4)

Table 7 - Communality Value on Implementation Method Factor

\begin{tabular}{|c|l|c|}
\hline $\begin{array}{c}\text { Manifest } \\
\text { Variables }\end{array}$ & \multicolumn{1}{|c|}{ Description } & $\begin{array}{c}\text { Communality } \\
\text { Value }\end{array}$ \\
\hline X5.1 & The appropriateness of the project implementation method with the planning & 0,703 \\
\hline X5.2 & The lack of ability in using the right method & 0,647 \\
\hline X5.3 & The project implementation is not in line with the specification & 0,297 \\
\hline X5.4 & The use of equipment, material, and workers which are not in line & 0,339 \\
\hline
\end{tabular}

Then, strategies used towards the factors affecting significantly the project implementation delay will be discussed. The Implementation Method factor is the variable which has the highest $\beta$ coefficient value. It means that the project implementation delay can 
be influenced by Implementation Method factor. The orders of the indicators affecting mostly the project implementation method can be seen in Table 7.

From table 7, it is known that the indicator of Implementation Method Factor which is the most dominant affecting Project Implementation Delay is respectively based on the highest value priority which can be seen in table 4.35 as follows:

Table 8 - Strategies Based on Priority on Implementation Method Factor

\begin{tabular}{|c|l|l|}
\hline $\begin{array}{c}\text { Manifest } \\
\text { Variables }\end{array}$ & \multicolumn{1}{|c|}{ Detail } & \multicolumn{1}{c|}{ Strategies } \\
\hline X5.1 & $\begin{array}{l}\text { The appropriateness of } \\
\text { the project } \\
\text { implementation method } \\
\text { with the planning }\end{array}$ & $\begin{array}{l}\text { In the implementation, it is found that the contracyor does not follow the } \\
\text { implementation method so that the owner must immediately make a } \\
\text { workframe of reference (KAK) and technical specifications in } \\
\text { accordance with a more complete and detailed plan as well as follows } \\
\text { time schedule/S curve which has been determined, so that the } \\
\text { contractor can implement the project with right implementation method. }\end{array}$ \\
\hline$\times 5.2$ & $\begin{array}{l}\text { The lack of ability in } \\
\text { using the right method }\end{array}$ & $\begin{array}{l}\text { In the implementation, it is found that the contractor is not able to follow } \\
\text { the implementation method so that the owner must immediately arrange } \\
\text { workframe of reference (KAK) and technical specifications in } \\
\text { accordance with a more complete and detailed plan so that the } \\
\text { contractor is abe to perform the work with the right implementation } \\
\text { method. }\end{array}$ \\
\hline$\times 5.4$ & $\begin{array}{l}\text { The project } \\
\text { implementation is not in } \\
\text { line with the specification } \\
\text { make a good analysis in using the equipment, material, or so on. The } \\
\text { strategy that can be taken is the contractor must make a good analysis } \\
\text { in using equipment, material or resources so that it is on time and costly } \\
\text { saved. }\end{array}$ \\
\hline X5.3 & $\begin{array}{l}\text { In work implementation, it is found that the contractor does not } \\
\text { not in accordance with } \\
\text { specification }\end{array}$ & $\begin{array}{l}\text { Implement it as in the specifications so that the strategy that can be } \\
\text { taken is the owner asks the contractor to make a request of each work } \\
\text { items before implementing the work so that it is in line with the } \\
\text { determined specifications. }\end{array}$ \\
\hline
\end{tabular}

\section{CONCLUSION}

From the result of regression model hypothesis testing simultaneously using $\mathrm{F}$ test, then the calculation result of $F_{\text {count }}$ is smaller than $F_{\text {table }}(1,079<2,270)$. Therefore, $p$-value is also obtained of 0.396 . If $p$-value compared to $\alpha=0.05$, then $p$-value is bigger than $\alpha=0.05$. From both comparisons, it is concluded that $\mathrm{H}_{0}$ is accepted in the standard of $\alpha=0.05$. Thus, it can be concluded that there is no a significant factor simultaneously among factors of $X 1$, $\mathrm{X} 2, \mathrm{X} 3, \mathrm{X} 4, \mathrm{X} 5, \mathrm{X} 6$ and $\mathrm{X} 7$ toward the project implementation delay.

The most dominant factor affecting the project implementation delay of building development in Human Settlements Division in East Kutai Regency is the Factor of Implementation (X5) having the regression coefficient $-0,086$. By using the help of SPSS, coefficient $\beta$ value of $-0,086$ and $p$-value is smaller than $\alpha=0.05$. This testing reveals that $H_{0}$ is rejected. Thus, it can be concluded the factor of Implementation Method affects significantly towards the project implementation delay.

The actions that need to be taken in order to minimize the building development project delay in Human Settlements Division in East Kutai Regency based on priority are:

- When developing, it is found that the contractor does not follow the implementation method, a workframe of reference (KAK) and technical spesifications with more complete and more detailed or follow time schedule/S curve so that the contractor can perform the work with a right implementation method.

- In the development, it is found that the contractor is not able to follow the implementation so that the owner must immediately make a workframe reference (KAK) and with more complete and more detailed or follow time schedule/S curve so that the contractor can perform the work with a right implementation method.

- In the work development, it is found that the contractor does not make a good analysis in using equipment, material, or others. The strategies that can be taken are 
the contractor must make a good analysis in using equipment, material, or others so that it is on time and costly saved.

- In project implementation, it is found that the contractor does not perform a work which is not in line with the specifications so that the strategy that can be taken is the owner askes the contractor to make a request of each work items before implementing the project so that it is in line with the determined specification.

\section{SUGGESTIONS}

Based on the result of research and analysis, the suggestions given to the related parties (Owner, Contractor, and Supervisor Consultant) to pay attention on these things as follows:

- The owner must determine the project implementation so that the project done is in line with what is planned and in line with the determined time. If the method is inappropriate, then the project will have a delay;

- The contractor attempts to follows the appropriateness of the project implementation method with planning and can use the right method and the project implementation is in accordance with specifications;

- The supervisor consultant must understand the working procedures and contract document and supervise as well as control the work based on SOP, so that the project;

- Implementation is in line with quality, volume, cost, and can be done punctually. Evaluating the result of implementation continuously and giving report to owner should also be done so that every problem can be solved immediately;

- Both Owner, contractor, and supervisor consultant must be able to use implementation time effectively in accomplishing the project so that extra working time is not occurring which causes to the delay of development project accomplishment;

- It is expected that the next researchers examine the other factors besides the factors in this present research affecting the project delay of building development in Human Settlements Division of Public Works Service Office of East Kutai Regency in which the factor of implementation method is the most significant factor affecting delay and other factors are assumed as other factors.

\section{REFERENCES}

1. Arikunto, S. 2006. Prosedur Penelitian (Suatu Pendekatan Praktek), Edisi revisi ke VI, Penerbit Rineka Cipta, Jakarta.

2. Chan, A.P. et al (2004). Factors affecting the success of a construction project. Journal of construction engineering and management, 130(1), 153-155.

3. Gould, F. E., \& Joyce, N. E. (2003). Construction project management. Upper Saddle River, NJ: Prentice Hall.

4. Kerzner, 2006. Project Management, a System Approach to Planning, Scheduling, and Controling, Ninth Ed. John Wiley \& Sons, Inc. USA.

5. Olander, S. (2007). Stakeholder impact analysis in construction project management. Construction management and economics, 25(3), 277-287.

6. Riduwan, 2005. Dasar-Dasar Statistik, Penerbit CV. ALFABETA, Bandung.

7. Smith, N. J. et al (2009). Managing risk: in construction projects. John Wiley \& Sons.

8. Soeharto, I. 2001. Manajemen Proyek, Edisi Kedua, Penerbit Erlangga, Jakarta.

9. Sturzenegger, D., Gyalistras, D., Morari, M., \& Smith, R. S. (2016). Model predictive climate control of a swiss office building: Implementation, results, and cost-benefit analysis. IEEE Transactions on Control Systems Technology, 24(1), 1-12.

10. Sugiyono, 2006. Statistika untuk Penelitian, Penerbit CV. ALFABETA, Bandung.

11. Supranto, J. 2000. Statistik Teori dan Aplikasi, Edisi Kedua, Penerbit Erlangga, Jakarta. 